\title{
Sexing of Subfossil Cattle Metacarpals
}

\author{
Øystein WIIG ${ }^{1}$ \\ Wiig Ø., 1985: Sexing of subfossil cattle metacarpals. Acta theriol., \\ 30, 30: 495-503 [With 3 Tables \& 2 Figs.] \\ Sexing of cattle metacarpals from bivariate scatter plots of pro- \\ ximal width, minimum diaphysial width and distal width against \\ total length, and their indices, were compared with the more sophi- \\ sticated principal component analysis. The work was based on 39 \\ complete bones from Mediaeval Bergen. It was shown that the plots \\ of distal width against total length was just as reliable as the prin- \\ cipal component analysis, whereas the plots based on proximal width, \\ minimum diaphysal width and total length were less reliable. \\ [Department of Systematic Zoology, Zoological Museum, University \\ of Bergen, Bergen, Norway].
}

\section{INTRODUCTION}

In the majority of zoo-archaeological studies sexing of long-bones is based on simple scatter plots of two or three dimensions. In some, however, such scatter plots are unable to disclose the existence of sexual dimorphism or trimorphism, and effective analysis requires the application of more sophisticated morphometric methods. In studies of sexual dimorphism in fossil remains multivariate methods are widely applied (Blackith \& Reyment, 1971). The application of such methods in studies of subfossil bones is, however, rare.

Wiig (1980) discussed the use of discriminant analysis to sex subfossil otter bones, with reference to the work of van Vark (1974). In the present work, the use of principal components analysis (PCA) to sex cattle metacarpals is compared to the more conventional method of bivariate scatter plots.

\section{MATERIAL AND METHODS}

The material used in the present study consists of 39 complete cattle metacarpals excavated at Rosenkrantzgt. 4, Bergen, Norway, in 1978 and 1979 under the supervision of the National Antiquarian. The material from two of the strata have earlier been analysed by Wiig (1981). The metacarpals used in the present study derive from two strata dated from the second half of the 15th century. A full description of the excavation site was given by Lindh (1980). The material is deposited at the Zoological Museum, University of Bergen.

1 Present address: Institute of Marine Research, Directorate of Fisheries, Box 1870, N-5011 Nordnes-Bergen, Norway. 
Higham (1969) pointed out that complete cattle metacarpals can be classified as cows, bulls or steers on the basis of the indices of proximal width and distal width to total length, and minimum diaphysial width to total length, based on the work of Zalkin (1962). The same four measurements were taken on each of the metacarpals in the present study and recorded to the nearest $0.05 \mathrm{~mm}$, and their indices were computed.

\subsection{Principal Component Analysis (PCA)}

Among multivariate morphometric techniques, PCA is preferred by many workers for studying size and shape variation (e.g. Thorpe, 1983). The aim of a PCA is to transform the original variables into new variables that have zero intercorrelation, so that the new axes define an independent pattern of variation that is not necessarily obvious in the original data (e.g. sexual variation).

When the PCA is computed from the covariance matrix, the contribution of a character to a component is indicated by the correlation between the character and the component scores (loading) (Blackith \& Reyment, 1971). The character relationships within the group can be interpreted by inspections of the sign and the magnitude of their loadings. Components expressing shape have loadings of different magnitude and/or sign, while components expressing general size have loadings of the same sign and similar magnitude (e.g. Thorpe \& Leamy, 1983). F'requently the first component reflects size variation and the other components reflect shape variation.

The characters were logarithmically transformed to make their inter-relationship linear and because components of a logarithmic variance-covariance matrix relate to possible proportional relationships between variables without a priori assumptions as to such ratios or indices (Pimentell, 1981). The principal components were extracted by the computer program BMDP4M (Dixon, 1981).

\section{RESULTS}

The four measurements, their indices and the component scores for each bone are given in Table 1, together with the sexual group assigned to each bone on the basis of the PCA. The character loadings for the four principal components and the percentages of the total variation accounted for by each component are set out in Table 2 .

The first component (PC1), which accounts for $76.9 \%$ of the variation, has all positive loadings. However, as the loadings for the total length is only half the size of the other three loadings, PC1 is not solely a general size component but includes shape variation of width in relation to length.

The second component (PC2) represents $13.7 \%$ of the total variation. This component almost entirely represents variation in total length of the metacarpals, as the loading for this dimension is highly significant $(P<0.001)$, while the loadings for the other three dimensions are not significantly different from zero $(P>0.05)$.

The third component (PC3) represents $6.9 \%$ of the variation. The 
Table 1

Dimensions (mm), indices and PCA scores (two first components) of 39 cattle metacarpals from Mediaeval Bergen, together with sex assigned to each bone based on the PCA. TL=total length, $\mathrm{PW}=$ proximal width, $\mathrm{MDW}=$ minimum diaphysial width, $\mathrm{DW}=$ distal width, $\mathrm{R} 1=\mathrm{PW} \cdot 100 / \mathrm{TL}, \mathrm{R} 2=\mathrm{MDW} \cdot 100 / \mathrm{TL}, \mathrm{R} 3=\mathrm{DW} \cdot 100 / \mathrm{TL}$,

\begin{tabular}{|c|c|c|c|c|c|c|c|c|c|c|}
\hline No & TL & PW & MDW & DW & R1 & $\mathrm{R} 2$ & R3 & PC1 & PC2 & Sex \\
\hline 1 & 156.3 & 41.9 & 24.2 & 44.7 & 26.8 & 15.5 & 28.6 & -1.83 & -1.02 & C \\
\hline 2 & 168.8 & 51.6 & 28.0 & 52.9 & 30.6 & 16.6 & 31.3 & 0.95 & 0.31 & $\mathbf{S}$ \\
\hline 3 & 166.2 & 53.7 & 30.2 & 55.7 & 32.3 & 18.2 & 33.5 & 1.82 & -0.46 & $\mathbf{S}$ \\
\hline 4 & 158.0 & 47.3 & 27.4 & 48.6 & 29.9 & 17.3 & 30.8 & -0.11 & -1.22 & $\mathbf{S}$ \\
\hline 5 & 158.7 & 47.9 & 27.2 & 49.5 & 30.2 & 17.1 & 31.2 & 0.01 & -0.99 & $\mathbf{S}$ \\
\hline 6 & 161.5 & 48.9 & 26.6 & 49.0 & 30.3 & 16.5 & 30.3 & -0.06 & -0.30 & $\mathbf{S}$ \\
\hline 7 & 181.5 & 51.2 & 29.0 & 54.4 & 28.2 & 16.0 & 30.0 & 1.39 & 1.20 & $\mathrm{~S}$ \\
\hline 8 & 158.8 & 49.2 & 26.4 & 51.8 & 31.0 & 16.6 & 32.6 & 0.19 & -0.55 & $\tilde{S}$ \\
\hline 9 & 178.7 & 48.8 & 27.5 & 49.8 & 27.3 & 15.4 & 27.9 & 0.38 & 1.18 & $\mathbf{S}$ \\
\hline 10 & 167.5 & 53.1 & 29.5 & 54.8 & 31.7 & 17.6 & 32.7 & 1.56 & -0.15 & $\hat{\mathbf{S}}$ \\
\hline 11 & 151.5 & 47.2 & 29.0 & 53.3 & 31.2 & 19.1 & 35.2 & 0.63 & -2.63 & B \\
\hline 12 & 158.8 & 48.4 & 27.9 & 49.7 & 30.5 & 17.6 & 31.3 & 0.22 & -1.15 & $\bar{S}$ \\
\hline 13 & 160.4 & 52.2 & 26.0 & 50.2 & 32.5 & 16.2 & 31.3 & 0.21 & 0.24 & $\mathrm{~S}$ \\
\hline 14 & 154.7 & 49.8 & 28.1 & 54.0 & 32.2 & 18.2 & 34.9 & 0.79 & -1.58 & $\mathrm{~S}^{1}$ \\
\hline 15 & 163.7 & 43.4 & 27.7 & 51.3 & 29.6 & 16.9 & 31.3 & 0.40 & -0.57 & $\mathrm{~S}$ \\
\hline 16 & 171.3 & 48.4 & 27.7 & 50.4 & 28.3 & 16.2 & 29.4 & 0.38 & 0.27 & $\mathbf{S}$ \\
\hline 17 & 164.1 & 46.0 & 26.8 & 50.1 & 28.0 & 16.3 & 30.5 & -0.14 & -0.56 & $\mathrm{~S}$ \\
\hline 18 & 164.3 & 50.5 & 27.0 & 49.1 & 30.7 & 16.4 & 29.9 & 0.21 & 0.10 & $\mathbf{S}$ \\
\hline 19 & 175.6 & 49.4 & 27.4 & 51.7 & 28.1 & 15.6 & 29.4 & 0.58 & 0.94 & $\tilde{S}$ \\
\hline 20 & 173.7 & 53.7 & 28.2 & 55.1 & 30.9 & 16.2 & 31.7 & 1.43 & 1.01 & $\mathbf{S}$ \\
\hline 21 & 176.8 & 50.4 & 27.7 & 52.9 & 28.5 & 15.7 & 29.9 & 0.86 & 1.08 & $\tilde{S}$ \\
\hline 22 & 166.2 & 52.1 & 28.3 & 53.4 & 31.3 & 17.0 & 32.1 & 1.08 & -0.01 & $\tilde{S}$ \\
\hline 23 & 159.1 & 49.7 & 29.3 & 50.9 & 31.2 & 18.4 & 32.0 & 0.76 & -1.42 & $\mathbf{S}$ \\
\hline 24 & 168.8 & 50.1 & 25.1 & 48.8 & 29.7 & 14.9 & 28.9 & -0.24 & 1.23 & $\tilde{\mathbf{S}}$ \\
\hline 25 & 155.8 & 43.1 & 26.5 & 46.3 & 27.7 & $\begin{array}{l}17.0 \\
\text {. }\end{array}$ & 29.7 & -1.00 & -1.78 & $\mathrm{C}$ \\
\hline 26 & 161.1 & 44.7 & 22.7 & 45.8 & 27.7 & 14.1 & 28.4 & -1.75 & 0.59 & C \\
\hline 27 & 162.8 & 51.7 & 26.0 & 49.9 & 31.8 & 16.0 & 30.7 & 0.16 & 0.45 & $\mathrm{~S}$ \\
\hline 28 & 167.8 & 46.2 & 23.7 & 45.6 & 27.5 & 14.1 & 27.2 & -1.30 & 1.16 & C \\
\hline 29 & 175.2 & 48.1 & 26.0 & 49.0 & 27.5 & 14.8 & 28.0 & -0.13 & 1.27 & $\mathbf{S}$ \\
\hline 30 & 162.6 & 46.8 & 23.8 & 46.6 & 28.8 & 14.6 & 28.7 & -1.16 & 0.62 & C \\
\hline 31 & 161.4 & 47.4 & 25.0 & 46.1 & 29.4 & 15.5 & 28.6 & -0.88 & 0.12 & C \\
\hline 32 & 156.1 & 45.5 & 25.4 & 46.3 & 29.1 & 16.3 & 29.7 & -1.00 & -0.94 & C \\
\hline 33 & 175.7 & 51.0 & 27.6 & 50.4 & 29.0 & 15.7 & 28.7 & 0.63 & 1.14 & $\mathbf{S}$ \\
\hline 34 & 172.5 & 46.3 & 24.6 & 48. & 26.8 & 14.3 & 28.0 & -0.73 & 1.25 & $\mathrm{C}^{2}$ \\
\hline 35 & 159.6 & 48.1 & 23.8 & 46.8 & 30.1 & 14.9 & 29.3 & -1.04 & 0.48 & C \\
\hline 36 & 169.5 & 45.6 & 24.8 & 44.7 & 26.9 & 14.6 & 26.4 & -1.18 & 0.83 & C \\
\hline 37 & 171.0 & 51.8 & 29.2 & 53.1 & 30.3 & 17.1 & 31.1 & 1.26 & 0.17 & S \\
\hline 38 & 151.4 & 45.3 & 23.8 & 44.4 & 29.9 & 15.7 & 29.3 & -1.67 & -0.86 & C \\
\hline 39 & 162.6 & 44.3 & 23.0 & 46.0 & 27.2 & 14.1 & 28.3 & -1.67 & 0.55 & C \\
\hline
\end{tabular}

1 Final sex S/B, 2 Final sex $\mathrm{S}$.

loadings for total length (negative) and proximal width are significantly different from zero $(P<0.01$ and $P<0.05$, respectively), while the other two loadings are not significantly different from zero $(P>0.05)$. Thus, this component contrasts total length against proximal width.

The fourth component (PC4) represents only $2.5 \%$ of the total variation. However, as none of the loadings are significantly different from zero $(P>0.05)$ this component is difficult to interpret. 

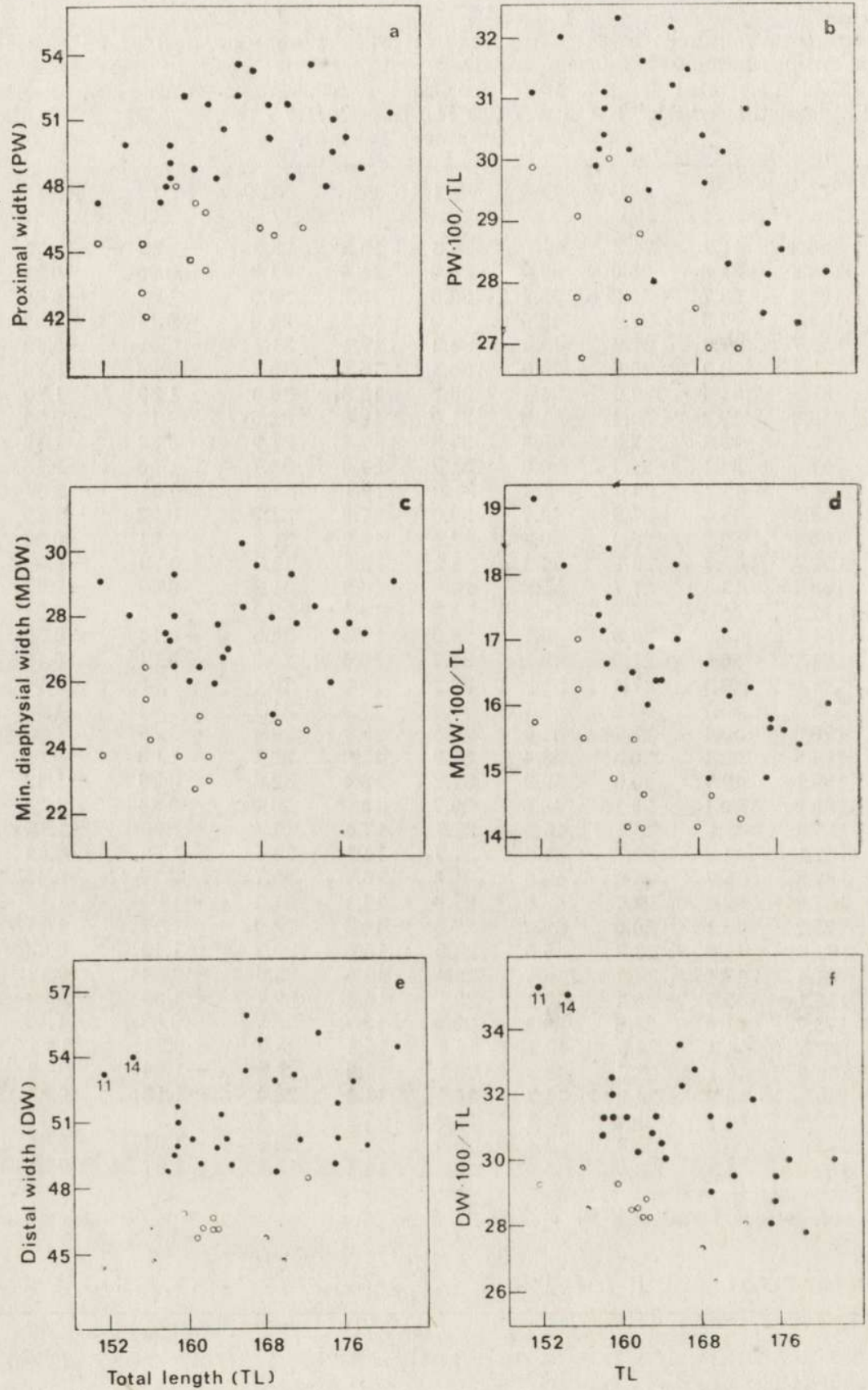

Fig. 1. Plots of cattle metacarpals from Mediaeval Bergen. The symbols reflect sexing based on a PCA (see Fig. 2). $O=$ females, $=$ males. The numbers refere to Table 1 . 
Figure 1(a-f) shows the plots of each measurement and each index against the total length, while Figure 2 shows the plots of the scores on $\mathrm{PC} 1$ and PC2. The component scores have been standardized to a zero mean and a standard deviation equal to one. The plots are given in symbols reflecting the sex assigned to the bones on the basis of the PCA (see Table 1).

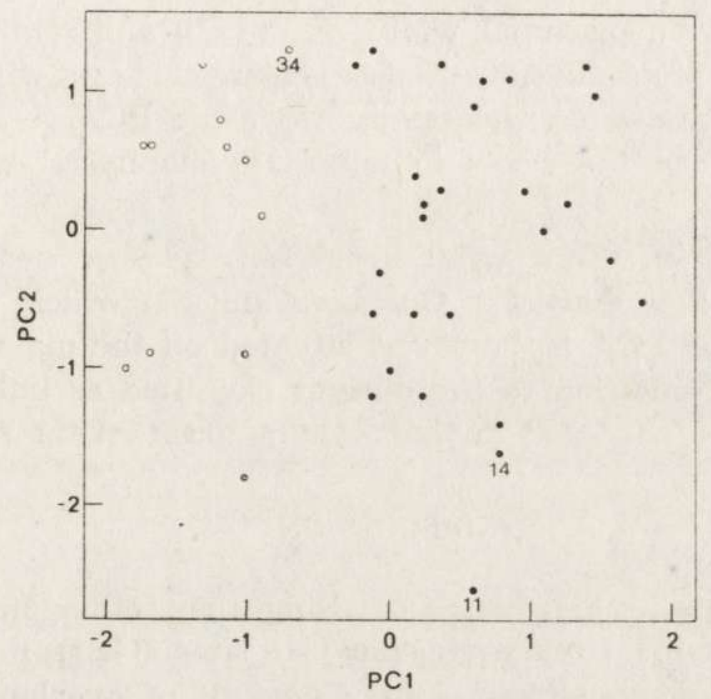

Fig. 2. Plots of PC scores of cattle metacarpals from Mediaeval Bergen. The symbols reflect the sex asigned to each bone. $O=$ female, $\bullet=$ males. The numbers refere to Table 1 .

\section{Table 2}

Character loadings ${ }^{1}$ calculated from a principal component analysis of four dimensions of cattle metacarpals from Mediaeval Bergen, Norway, and the percentage of the total variation accounted for by each component. The components are extracted from the logaritmized variance-covariance matrix.

\begin{tabular}{llccc}
\hline & PC1 & PC2 & PC3 & PC4 \\
\hline Total length & 0.420 & 0.830 & -0.371 & -0.004 \\
Proximal width & 0.879 & 0.257 & 0.381 & -0.132 \\
Minimum diaphysial width & 0.933 & -0.270 & -0.206 & -0.110 \\
Distal width & 0.968 & -0.036 & 0.051 & 0.250 \\
Percentage variation & 76.9 & 13.7 & 6.9 & 2.5 \\
\hline
\end{tabular}

1 Correlation between dimension and component scores.

On PC1 two groups are disclosed. Twelve bones have standard scores less than -0.72 (called G1) while the other 27 metacarpals have scores higher than -0.25 (called G2). Thus, there seems to be one group of animals with narrow metacarpals and one with broad metacarpals. 
On PC2 there is one outlyer with a standard score equal to -2.63 (no 11). Another interesting feature of the distribution of the scores on this component is that G1 is divided into two subgroups, one with PC2 scores less than -0.50 containing four specimens, and one group with scores larger than zero containing eight specimens. G2 (excluding specimen no 11) seems to be subdivided into several subgroups. Such groupings are not found equally clear on PC3 and PC4.

The plots based on proximal width (Fig. 1a,b) and minimum diaphysial width (Fig. 1c,d) do not disclose clear clusters with regard to sexing. However, based on the sexing from the PCA it appears to be less overlap between the sexes in minimum diaphysial width than in proximal width.

The plots based on distal width (Fig. 1e,f) disclose nearly the same main clusters as PC1 and PC2. One bone (no 34) which was classified as female from the PCA is, however, situated on the main male cluster on these plots. In addition to the outlyer classified as bull from Fig. 2 (no 11) also no 14 has such an outstanding position on Fig. 1e,f.

\section{DISCUSSION}

Metapodials seem to be more promising than other limb bones for sexing cattle remains from archaeological sites (Grigson, 1982). However, Fock (1966) demonstrated a high amount of overlap between the sexes, particularly in the case of castrates in relation to the other two groups. Since the size and shape of the metacarpals is sexually trimorphic, detailed statistical analysis of this particular bone was recommended by Higham (1969).

The use of PCA in numerical taxonomy often shows that taxa are separated on the first components and that the subsequent components represent a compromise between racial variation within various taxa (Thorpe, 1983). Two groups are disclosed on the first component. This component separates between narrow and wide metacarpals, as the total length has a loading of less than half the size of the loadings of the width dimensions. Among cattle, male metacarpals are generally wider than female metacarpals (e.g. Howard, 1963; Fock, 1964; Higham, 1969). In accordance with this, the metacarpals of group G1 are assumed to come from cows, while the bones in G2 are assumed to come from steers and bulls.

The sexing based on distal width and total length gave nearly the same result as that based on the PCA. Bone no 34 has an intermediate position between males and females on Fig. 2 based on the latter analysis. Because this bone is clearly situated among males in the plots 
based on distal width and total length, the bone is believed to be a male.

Bulls are usually found to have shorter and stockier metacarpals than steers (e.g. Howard, 1963; Fock, 1964; Grigson, 1982). Bone no 11 is the shortest metacarpus among males (total length $=151.5 \mathrm{~mm}$ ), while the indices minimum diaphysial width to total length and distal width to total length are very high (19.1 and 35.2, respectively). This bone is therefore believed to be a bull.

Also bone no 14 has a broad distal width in relation to its total length, which results in a high index (34.9). The score of no 14 on $\mathrm{PC} 2$ is, however, much higher than the score of bone no 11 . Whether bone no 14 origin from a bull or a steer seems accordingly unceitain.

The rest of the metacarpals are classified as steers from both methods (Fig. 1e,f and Fig. 2).

In an earlier work (Wiig, 1980), 27 of the metacarpals studied in the present work were sexed from the index of minimum diaphysial

Table 3

Range in four dimensions $(\mathrm{mm})$ and three indices of cattle metacarpals from Mediaeval Bergen, Norway.

\begin{tabular}{|c|c|c|}
\hline & $\begin{array}{l}\text { Cows } \\
\mathrm{n}=11\end{array}$ & $\begin{array}{l}\text { Steers } \\
\mathrm{n}=26\end{array}$ \\
\hline Total length & $151.4-169.5$ & $154.7-181.5$ \\
\hline Proximal width & $41.9-48.1$ & $46.0-53.7$ \\
\hline Minimum diaphysial width & $22.7-26.5$ & $24.6-30.2$ \\
\hline Distal width & $44.4-46.8$ & $48.3-55.7$ \\
\hline Proximal width $\cdot 100 /$ total length & $26.8-30.1$ & $26.8-32.5$ \\
\hline Minimum diaphysial width $\cdot 100 /$ total length & $14.1-17.0$ & $14.3-18.4$ \\
\hline Distal width $100 /$ total length & $26.7-29.7$ & $27.9-33.5$ \\
\hline
\end{tabular}

width to total length. One of these bones was then classified as female, the others as mainly steers. In the present analysis three of these 27 bones are situated in the female cluster. The very skewed sex ratio found in that earlier work was supported by the ratio 4:19 female to male pelves, which also seems to support the results of the present analysis. The sex-identification from the present analysis is, however, believed to be more correct than that in the former work. This is because the identification in the 1981-work was based on the indices given by Howard (1963) calculated from recent breeds, while the distinction between female and males in the present work is based on the relative variation within the analysed sample.

Table 2 shows the ranges of the four dimensions measured together with the three calculated indices for cows and steers. The range of the total length of those classified as cows falls almost entirely within the 
range of those classified as males, while the overlap of the ranges of proximal width and minimum diaphysial width is much less. In distal width the assumed sexes are disjunct. This is a similar pattern as reflected in the loadings of the first principal component.

The presence of two subgroups among the females might indicate that there were two different breeds among the cattle, with different metacarpus length. If there really are two breeds among the cattle, this pattern should also be reflected among the male metacarpals, as Fock (1964) demonstrated that the dimensions of metacarpus and their indices vary for different breeds. In accordance with this bone no 14 could be a bull from the breed having the largest scores on PC2. However, more research is needed to proove that the were two breeds of cattle in Mediaeval Bergen.

The present work has shown that a bivariate scatter plot of distal width against total length is just as reliable to sex cattle metacarpals as the more sophisticated PCA. If one takes into consideration the ease of calculation, the first method is much better than the latter which is more time consuming. In the present work, however, the PCA did seem to give more information about clustering within the sexes than the bivariate plots. The use of proximal width and minimum diaphysial width compared to total length did not turn out to be as effective as the other two methods for sexing cattle metacarpals.

Acknowledgements: I am grateful to E. Pierce for revising the English text.

\section{REFERENCES}

1. Blackith R. E. \& Reyment R. A., 1971: Multivariate morphometrics. Academic Press: $1-412$, London, New York.

2. Dixon W. J., 1981: BMDP Statistical software. University of California Press: $1-725$, Berkeley.

3. Fock J., 1966: Metrische Untersuchungen an Metapodien einiger Europäischer Rinderrasen. Diss. München: Institut für Palaeoanatomie, Domestikationsforschung und Gesichte der Tiermedizin der Universität München.

4. Grigson C., 1982: Sex and age determination of some bones and teeth of domestic cattle: a review of the literature. [In: "Aging and sexing animal bones from archaeological sites", eds B. Wilson, C. Grigson \& S. Payne). British Archaeological Reports, British Ser. 109: 7-23, Oxford.

5. Higham C. F. W., 1969: The metrical attributes of two samples of bovine limb bones. J. Zool., 157: 63-74.

6. Howard M., 1963: The metrical determination of the metapodials and skulls of cattle. [In: "Man and cattle" eds A. E. Mourant \& F. E. Zeuner]. Royal Anthropological Society Occasional Paper 18: 91-100.

7. Lindh J., 1980: Rapport over de arkeologiska undersökningarna i Rosenkrantzgaten 4, Bergen. (Unpubl. rep.) 
8. Pimentel R. A., 1981: Morphometrics. The multivariate analysis of biological data. Kendal/Hunt Publising Company: 1-276, Dubuque.

9. Thorpe R. S., 1983: A review of the numerical methods for recognizing and analysing racial differentiation. [In: "Numerical taxonomy", ed. J. Felsenstein]. Springer-Verlag: 404-423, Berlin, Heidelberg.

10. Thorpe R. S. \& Leamy L., 1983: Morphometric studies in inbred and hybrid House mice (Mus sp.): Multivariate analysis of size and shape. J. Zool., 199: $421-432$.

11. Vark G. N. van, 1974: The investigation of human cremated skeletal material by multivariate statistical methods. 1. Methodology. Ossa 1: 63-95.

12. Wiig Ø., 1980: Methods for sex-identification of subfossil bones. J. Zool., 192: $543-546$.

13. Wiig Ø., 1981: Faunal remains from Mediaeval Bergen. Fauna norvegica, Ser. A, 2: $34-40$.

14. Zalkin V., 1982: Livestock raising and hunting in the woodland strip of Europe. Materials and studies concerning the archaeology of the Soviet Union 107: $1-140$

Accepted, April 2, 1985.

\section{Øystein WIIG}

\section{OKRESLANIE PECI U BYDEA NA PODSTAWIE SUBFOSYLNYCH ZNALEZISK KOSCI SRÓDRĘCZA}

\section{Streszczenie}

Autor oparł się na badaniach 39 kompletów kostnych śródręczy bydła; odkopanych w okolicach Bergen w Norwegii. Pochodzily one $z$ drugiej polowy XV wieku. Przy kwalifikowaniu kości do odpowiedniej płci (byki, krowy i kastraty) używał wskaźników: szerokości proksymalnej i dystalnej do całkowitej długości oraz najmniejszej szerokości diafyzalnej do całkowitej długości. Wskaźniki te następnie poddal analizie statystycznej (Principal Component Analysis - PCA) (Tabela 1, 2,3 ; Ryc. 1,2 ).

Na podstawie uzyskanych wyników stwierdza, że wskaźnik szerokości dystalnej do całkowitej długości jest tak samo wiarygodny jak PCA, natomiast wskaźniki oparte na szerokości proksymalnej, najmniejszej szerokości diafyzalnej i całkowitej długości są mniej wiarygodne. 